\title{
Evaluating user education programmes for postgraduate students in the School of Management, Information Technology and Governance at the University of KwaZulu-Natal
}

\author{
Smangele Pretty Moyane ${ }^{1}$, Luyanda Dube ${ }^{2}$ and Ruth Hoskins ${ }^{3}$ \\ smangeleM1@dut.ac.za ORCID: orcid.org/0000-0002-4963-8326 \\ dubel@unisa.ac.za ORCID: orcid.org/0000-0001-6525-0797 \\ hoskinsr@ukzn.ac.za ORCID: orcid.org/0000-0002-9099-5544
}

\begin{abstract}
Received: 3 March 2015
Accepted: 10 July 2015

Notwithstanding the wealth of information available in the knowledge economy, many academic library users still lack essential knowledge and skills to locate materials. This deficiency might be attributed to the fact that the information environment is complex and is changing quickly. The main purpose of a university library is two-fold. It involves providing information sources relevant for learning, teaching and research. It also involves empowering users by furnishing them with knowledge and skills that will assist them to be independent and lifelong users. The library is regarded as the core of any educational institution, particularly a university. The study described in this paper was conducted to investigate the effectiveness of user education programmes for postgraduate students in the School of Management, Information Technology and Governance at the University of KwaZulu-Natal, Westville Campus. The study used both quantitative and qualitative research approaches, employing questionnaires for postgraduate students and interviews for subject librarians and academic coordinators. These data collection tools were presented sequentially, with questionnaires for students followed by interviews with library and academic coordinators. The findings revealed that, although there are pockets of good practice in user education, there is a need to reconsider the content, the mode, the scope, presentation strategies and overall relevance and suitability of user education programmes in line with user needs. There is also a need to consider issues of appropriateness, effectiveness and efficiency of instructional methods and pedagogical matters.
\end{abstract}

Keywords: User education, library instruction, library orientation, information literacy, bibliographic instruction and academic library.

\section{Introduction}

The development of technology has impacted on the evolution of the information environment which, by extension, has led to the proliferation of diverse and complex information sources (Brandenburg \& Song 2012; Breen \& Fallon 2005; Isiaka \& Olaide 2013) and has necessitated libraries re-examining and re-engineering their fundamental role. Although the evolving information landscape offers wide-ranging information options (Chen 2012; Fawley \& Krysak 2012), it might overwhelm the average library user who lacks the essential knowledge, skills and techniques to comprehend and navigate it (Aderibigbe \& Ajiboye 2011; Breen \& Fallon 2005; Ogunmodede, Adio \& Odunola 2011; Owusu-Ansah 2004; Suleiman 2012; Wooliscroft 1997). Similarly, this evolving landscape requires huge investments in an era characterised by economic turmoil (Stone \& Ramsden 2014), forcing libraries to compete for financial support with other important enterprises within parent institutions. Competition has heightened the urgency for libraries to justify not only their costs but also their worth and existence by ensuring returns on investment (Powell 1992, in Whitmire 2002). To prove their worth, libraries need to be able to demonstrate that their resources and services are used effectively and optimally to enable the parent organisation to meet its goals and targets (Breen \& Fallon 2005; Chen 2011). What emerges from the foregoing discussion is that, because of the quantity and complexity of information as well as the economics of this commodity and the apparent pressure to prove return on investment, libraries need to prioritise user education and equip the user with skills to navigate and explore information resources.

Although the assertion above is true for all libraries, it is particularly true for academic libraries as they usually have huge, costly and complex collections intended to support their universities in their quest to develop graduates with the skills to be self-directed lifelong learners, capable of assuming greater control over their own learning (Anyira 2011; Breen \& Fallon 2005; Chen 2011; Maduako 2013). Various authors assert that access to information, as well as its effective and efficient use, can have a positive impact on academic performance of students and enhances teaching and research outputs in a university (Aderibigbe \& Ajiboye 2011; Bhatti 2010; Breen \& Fallon 2005; Hindagolla 2012; Isiaka \& Olaide

1. Smangele Pretty Moyane is a lecturer in the Department of Information and Corporate Management, Durban University of Technology.

2. Luyanda Dube is Associate Professor in the Department of Information Science, University of South Africa.

3. Ruth Hoskins is Professor in the Information Studies Programme, University of KwaZulu-Natal. 
2013; Maduako 2013; Ogunmodede, Adio \& Odunola 2011; Owusu-Ansah 2004; Stone \& Ramsden 2014; Suleiman 2012; Umeozor 2013; Wong \& Webb 2011). These authors attest to a correlation between mastering the use of the academic library and improved academic performance. If this is the case, the academic library of the twenty-first century which is the hub of information and the epicentre of learning, not just an appendix or adjunct - has to realise that merely focusing on the collection size, circulation, and usage statistics may not be sufficient to remain in a competitive and viable position within the institution (Chen 2011). Thus, academic libraries need to produce empirical evidence that library usage does contribute positively to student academic performance. However, Wong \& Webb (2011) caution that it is still a challenge for most academic libraries to demonstrate in a scientific manner their value to and impact on the university's academic mission.

The focus of this paper is user education in academic libraries, in the University of KwaZulu-Natal (UKZN) Westville Campus Library in particular. Given that user education is one of the catalysts for library use, this paper will begin by illuminating the broader context of the prominence and implications of user education before dealing with the specifics of user education.

\section{The context: University of KwaZulu-Natal Library}

UKZN is the largest contact teaching, higher education institution in South Africa. UKZN was constituted on 1 January 2004 as a result of the merger between the University of Natal, a historically white university, and the University of Durban-Westville, a historically Indian university. It is a multi-campus, residential, teaching and research-led university located in the picturesque province of KwaZulu-Natal. The mission statement of the university is to be the "premier university of African scholarship", marking the end of the apartheid-style institution. The university hosts the College of Law and Management Studies on three campuses. The College is one of the four Colleges that form the university. In turn, it consists of four Schools: the Graduate School of Business and Leadership; the School of Accounting, Economics and Finance; the School of Law; and the School of Management, Information Technology and Governance. Three of the Schools are based on the Westville Campus, with the School of Law being based at the Howard College Campus. There are a variety of programmes that are offered by the three Schools at the Westville Campus. For the purpose of this research, the study was limited to the School of Management, Information Technology and Governance which was the former Faculty of Management. The university has five campus libraries and several branch libraries (seventeen libraries in total), distributed across two cities (Durban and Pietermaritzburg). The libraries play an integral part in supporting equal and equitable access to information through their print and electronic resource network (UKZN 2013).

\section{Statement of the problem}

The university library is the heart of the university; teaching and research depend upon the library, and achievements in teaching and research may be hampered without the library (Mohammadi, Moghaddam \& Yeganeh 2008). Although most university libraries have extensive collections ranging from print to electronic resources, it has emerged in the literature that most university students are unable to use information resources effectively and efficiently (Aderibigbe \& Ajiboye 2011; Blummer, Kenton \& Song 2010; Bundy 2004; Breen \& Fallon 2005; Suleiman 2012). The fact that most students are still unable to explore and use library resources is proof that, without a concerted effort to empower and capacitate students with skills, knowledge and attitudes to use information effectively, the existence of information in large quantities is not likely to benefit the user; sheer abundance of information and supporting technologies does not in itself create more informed students (Aderibigbe \& Ajiboye 2011; Blummer, Kenton \& Song 2010, Bundy 2004; Breen \& Fallon 2005; Ogunmodede, Adio \& Odunola 2011; Owusu-Ansah 2004; Suleiman 2012). This study focuses on a South African university where students come from diverse backgrounds, cultures and experiences. Diversity in the user population is often reflected in positive or negative library experiences, developed or underdeveloped library culture, as well as different levels of appreciation, understanding and orientation (Suleiman 2012). The discrepancy in library experiences amongst library users is evident in underdeveloped or developing environments which are characterised by high levels of poverty, low levels of literacy, and the marginalisation of libraries in national priorities. Usually in a deprived environment, people do not have a strong library background because of lack of exposure and experience.

If this is the reality for universities, it is also a reality for academic libraries. In their evolution, academic libraries have to comprehend the implications of serving a diverse user group and develop strategies to accommodate the diversity and to level the playing fields so that students can benefit from the information resources provided by the library. User education is one of the strategies that libraries can use to convert non-users into habitual users by moulding and equipping them with relevant skills, knowledge and attitudes that can reduce the discrepancy between the knowledge and use of collections (Kumar 2009). Chinyere (2014) notes that user education creates a connection between the users and the materials or tools; its significance for the library cannot be overemphasised. Without this intervention, the user who may not have any prior library experience or who has probably only had access to much smaller school and public libraries might be marginalised (Aderibigbe \& Ajiboye 2011; Breen \& Fallon 2005; Ogunmodede, Adio \& Odunola 2011; Owusu-Ansah 2004; Suleiman 2012; Wooliscroft 1997). If not properly addressed, poor knowledge of the services and resources of libraries and how to use them can be a lacuna that is likely to perpetuate under-utilisation of library services (Ogunmodede, Adio \& Odunola 2011; Owusu-Ansah 2004; Tiefel 1995). Likewise, it will negate the fundamental academic canon of developing independent and self-reliant individuals capable of finding and using information in an efficient, ethical and responsible manner (Coonan 2011; Fallon \& Breen 2012; Isiaka \& Olaide 2013; Okoye 2013; Suleiman 2012). It is thus the responsibility of the library to extend social equality and justice by enabling users, not only 
to access but also to use information effectively and efficiently. This responsibility is even more important to an institution that strives to be a "premier university" that seeks to redress past imbalances and traditions.

In a world where, as many analysts believe, access to information is not only important for survival but the key to prosperity, the need for tertiary graduates to acquire and develop information literacy skills is prevalent (Feast 2003:81, in Jiyane \& Onyancha 2010). Similarly, in an era where most universities promote the importance of quality education and "graduateness" (University of South Africa 2007) - the students' ability to perform optimally in the job market - the library can play a critical role in negating what Bhatti (2010) and Chinyere (2014) refer to as a "debasement of quality of university education".

Despite the recognition that user education is capable of adding value to university education, in particular academic outcomes, it has emerged from the literature that, in certain circumstances, user education can be ineffective. Like any other initiative or project, user education is susceptible to pitfalls which, if not well anticipated and managed, can be barriers to the effective implementation of user education. Some of the factors that could inhibit the successful implementation of user education include, but are not limited to, the following: poor planning; lack of strategic direction and commitment by library management; lack of cooperation from stakeholders, including academics and students; inappropriate communication strategies and tools; lack of human, financial and time resources; uninteresting, irrelevant, inappropriate and unresponsive programmes; low uptake; and inappropriate time allocation and time management (Blummer, Kenton \& Song 2010; Chen 2011; Fallon \& Breen 2012; Maduako 2013; Ogunmodede, Adio \& Odunole 2011). The same authors further suggest strategies that could be used to counteract these inhibitors and they include: proper planning and coordination; prioritising as part of the library's core agenda; using skills audit results to inform user education programmes; aligning with or embedding user education programmes into subject domains; implementing progressive programmes instead of once-off initiatives; adopting a participatory and inclusive approach; and improving communication strategies.

Key to the success of user education is the fact that the library itself and the user have to appreciate and understand the value of user education. If the library appreciates the value of user education, it will realise that the common practice of bringing students to the library for a one-to-two-hour session at the beginning of the academic year (when students are not even aware of their information needs) is inappropriate, ineffective and inefficient (Birch 2012; Maduako 2013; Kannappanavar \& Swamy 2012; Ogunmodede, Adio \& Odunole 2011). Practice has shown that, because these sessions are often non-compulsory and not linked in terms of assessment with their courses, attendance is often low (Breen \& Fallon 2005).

\section{The purpose and objectives of the study}

This study intended to examine user education programmes for postgraduate students in the School of Management, Information Technology and Governance at the Westville Campus, UKZN. In particular, the study looked at the extent to which students' perceptions about their skills matched their demonstrated skills. The objectives of the study are:

- To identify user education strategies and policies at the Westville Campus Library.

- To examine user education programmes for postgraduate students.

- To examine the problems experienced by subject librarians in terms of current user education programmes.

\section{Deconstructing the concept of user education: review of the literature}

This section provides a synopsis of the definition, origins, essence and theoretical foundation of the term 'user education'.

\subsection{Definition of the term 'user education'}

The realisation that the availability of materials in the library does not equate their accessibility has necessitated the introduction of an intervention that will develop skills necessary to achieve a higher degree of competence in the use of information resources and services (Adio \& Odunola 2011; Akakandelwa 2000; Oyedipe \& Okewale 2012). 'User education' is the umbrella term to describe a range of activities - from basic guidance in library layout to the more formal, structured and systematised programmes of instruction or training - on the effective and efficient use of information resources, materials, services and retrieval systems (Kannappanavar \& Swamy 2012; Tiefel 1995). User education is meant to improve the users' knowledge of the library's collections and services and to be a motivating factor for patronage, change of attitude, higher usage and more demands on the library (Okoye 2013). In the same vein, it is an attempt to change individual behaviour towards and experience of the use of library and other information sources (Lwehabura 1999, in Oyedipe \& Okewale 2012). This paper adopts the definition presented by Bhatti (2010), that user education entails systematic efforts to teach a set of principles or search strategies relating to the library, its collections or services using pre-determined methods in order to accomplish a defined set of objectives.

There are various terms used interchangeably with the term 'user education'. They are 'library instruction', 'reader instruction', 'library education', 'library orientation', 'bibliographic instruction' and 'information literacy' (Aderibigbe \& Ajiboye 2011; Blummer, Kenton \& Song 2010; Isiaka \& Olaide 2013; Jiao \& Onwuegbuzie 2004; Siddiqui \& Walia 2013; Umeozor 2013). Although the different terms have been used interchangeably, it is clear that there are significant differences that have been overlooked. For instance, user education offers comprehensive instruction in the use of information resources, while library orientation lacks the in-depth focus found in user education (Ogunmodede, Adio \& Odunola 2011). In the same vein, although the term 'information literacy' has been incorrectly employed to describe 
library user education and bibliographic instruction, the term is much more encompassing, including the strategic value and use of information to advance individual and collective progress (Wooliscroft 1997).

\subsection{Geneses of user education}

User education has its origins as far back as the nineteenth century, when a librarian was seen lecturing to undergraduates at Harvard College in the United States of America (Ogunmodede, Adio \& Odunole 2011; Tiefel 1995). User education in libraries evolved because it was realised that some users did not possess practical and complex intellectual skills, habits and attitudes that would enable them to seek, evaluate, use and create information effectively to achieve their personal, social, occupational and educational goals effectively and efficiently (Akakandelwa 2010; Kumar 2009). The basic intent of library user education is to be an instructional pedagogy (Coonan 2011; Hindagolla 2012); a method of enabling users to become information literate and self-sufficient (Maduako 2013; Syaikhu 2013); a lever to empower them to become their own gatekeepers of knowledge; a continuum of skills, behaviours, attitudes and values which enable users to navigate the ever-changing information arena (Ogunmodede, Adio \& Odunola 2011). Although the technologies, the tools, the content, the methods, the nature, and focus of user education has progressed significantly over the years as per the dictates of the changing information environment, the fundamentals of the practice have remained the same.

\subsection{Why user education?}

User education is a key factor in the knowledge economy and a tool to overcome the problems imposed by the evergrowing mass of information delivered in a variety of formats (Chen 2011; Coonan 2011; Fallon \& Breen 2012; Maduako 2013; Singh \& Nazim 2008; Suleiman 2012; Syaikhu 2013; Umeozor 2013). Generally, libraries are service institutions that have a mandate to provide information services to potential users or consumers. If, for any reason, these services are deficient it may mean that libraries have failed to deliver on their core mandate. To heighten the appreciation and use of the library as the information hub, user education is critical to ensure that users get continuous guidance on how to access, evaluate, and handle information in all its levels and forms. To be responsive to the ongoing developments in the information landscape, libraries constantly have to re-orientate, redefine and re-engineer their services (Coonan 2011). This means that the role of librarians has to shift from gatekeepers of information to key enablers, capable of empowering users to become more self-sufficient in information gathering and evaluation and use (Wooliscroft 1997). Embedded in the new role of librarians is responsibility to reform user education from the prescriptive and instructional approach to an outcomes-based educational approach (Chen 2011; Coonan 2011; Fallon \& Breen 2012; Singh \& Nazim 2008; Suleiman 2012).

\subsection{Theoretical paradigm for teaching user education}

As already indicated, user education is the instruction given to readers to help them make the best use of the library. Given that the core of user education is to teach - to impart knowledge, skills and attitudes - it is imperative that the teaching technique be appropriate. Although it is undisputed that library instruction has foundations in educational pedagogies including liberal, traditional, behavioural, progressive, and radical orientations, there is a continuing need for research into the pedagogical basis of library instruction, and the application of educational theories and methodologies to actual library instruction (Dewald 1999; Saunders 2002). Various authors claim that the theory of constructivism is an effective choice for user education as it recognises that users have their own mind and thought processes and relate things to previous experience (Arp 1993; Atherton 2005; Cooperstein \& Kocevar-Weidinger 2004; McCauley 2006). These theorists argue that constructivist learning is inductive. Thus, it assumes that students' reflection on their experiences helps to construct their new understanding and may empower them to apply strategies learnt or skills demonstrated. Because user education should be based on the principle of self-development, constructivist learning that accentuates discovery learning, active learning, hands-on learning, participatory learning, inclusive learning, cooperative learning and learner-centeredness is apt as a teaching strategy (Saunders 2002).

\subsection{Methods of teaching user education}

The traditional mode of teaching user education entails tutoring: demonstrations that are meant to show students the basics of navigating the information terrain (Sellie 2011). Saunders (2002) cautions that, as with all instruction, teaching methodology used by instructors in library instruction and information literacy has a profound effect on learning. Due to technological developments and emerging influences, expectations and trends prevalent in the knowledge economy, the traditional modes and strategies of teaching have to be reconsidered. Dewald (1999) proposes that libraries should consider web-based instruction to complement classroom instruction by expanding the librarian's teaching options and by expanding the student's options of being taught at times and places convenient to them. However, he cautions that online tutorials cannot completely substitute a human connection in learning (Dewald 1999). Figure 1 below presents alternative methods for teaching user education. The methods are in line with the constructivist theory discussed earlier, that champions student-centeredness and active learning.

The advantage of the alternative modes as presented in Figure 1 is that students do not need to be physically present in the venue. Secondly, those who missed training can still be trained via web-based tutorials or instructions. Thirdly, workshops during weekend and evening hours can try and reach students who are not available at other times 
(Saunders 2002). Lastly, through the variety of options, there is flexibility to accommodate the diversified and unique needs of the library clientele who simply cannot be accommodated in any of the scheduled times.

Figure 1 Methods of teaching user education

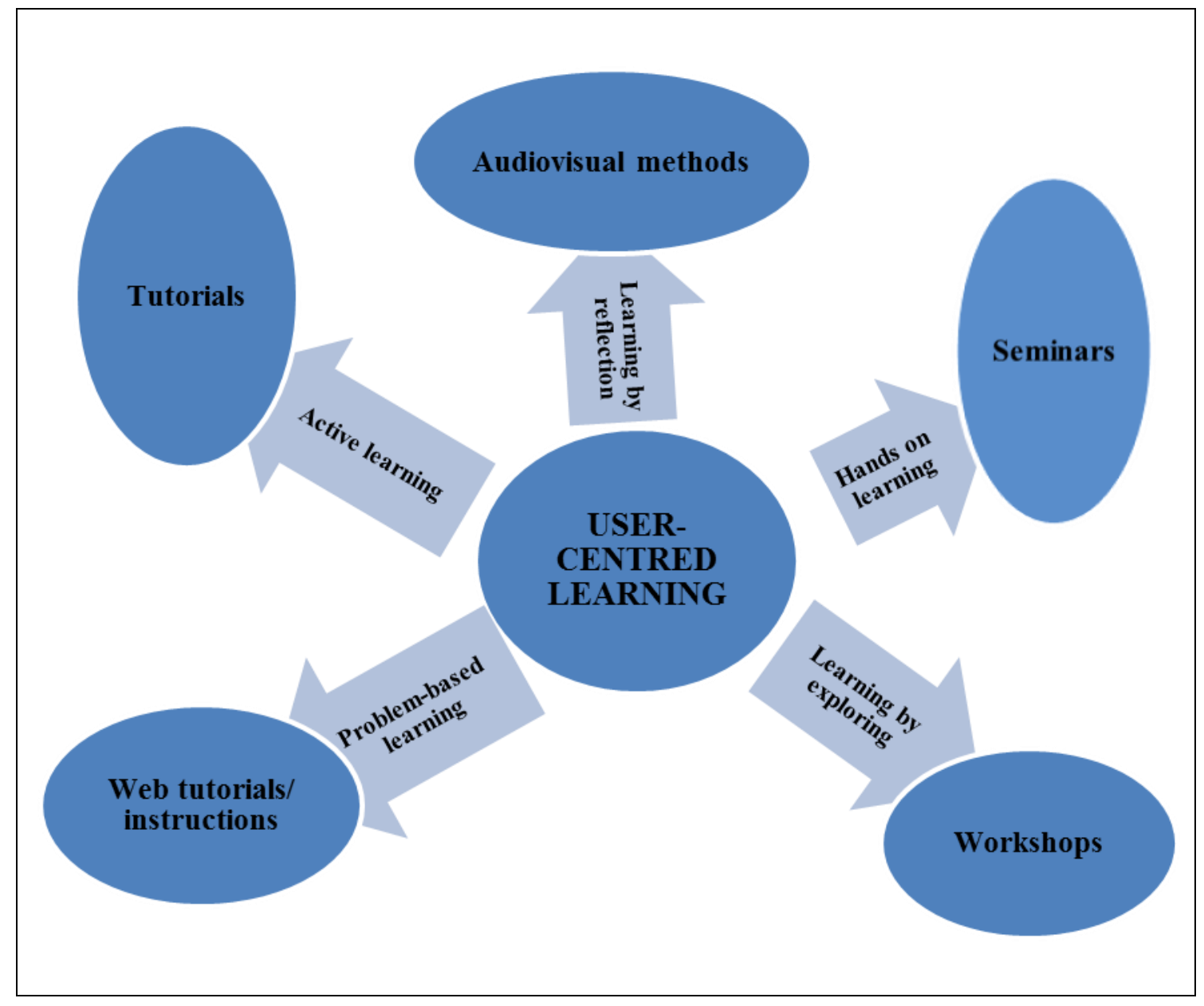

\subsection{Teaching user education: caveats and considerations}

Teaching and learning is a complex process wherein factors such as the learner, the content, the facilitator, teaching methods, learning styles and other mitigating factors have to be carefully considered. In the same vein, Saunders (2002) states that the design and implementation of a library class or course will be driven largely by the teaching methods (such as problem-based learning, collaborative learning, and hands-on learning), tools (such as presentation software or electronic classrooms), and the nature of the class (such as credit, non-credit, course-integrated, or optional) as well as the learners' needs.

As indicated earlier, the role of librarians has evolved from being information providers to facilitators of teaching and learning or library educators. This conviction begs the question, are librarians competent to teach user education? Are they confident in and prepared for pedagogical work? A study conducted by Heidi on Masters of Library and Information Science (MLIS) programmes revealed that very few LIS schools provide preparation in instructional and pedagogical skills because pedagogy and instruction do not occupy the same status as reference, cataloguing, collection development and other core LIS skills (Jacobs 2008). The critical question is: if LIS education does not include the component of education and training, where will graduates gain instructional expertise? Elmborg (2006) and Jacobs (2008) advocate for the transformation of LIS education and training by incorporating into the curriculum basics of methods of instruction and teaching styles (Jacobs 2008; Saunders 2002) as well as pedagogical theory (Elmborg 2006). This proposed inclusion may enhance the librarians' sense of preparedness in their instructional roles (Jacobs 2008). It may also enable them to understand the link between the audience, the content, and sound instructional strategies and techniques (Saunders 2002). Similarly, it can foster reflective, critical habits of mind regarding pedagogical praxis (Elmborg 2006). Gaining more understanding of the context of the user will enable instruction librarians to create a meaningful educational environment and enduring library instruction programmes that meet the users' current and future needs (Saunders 2002).

Based on the preceding arguments, a question that could arise is whether librarians really need to have training on instruction and pedagogy. Those who support this training argue that the library has an obligation to show students how to retrieve and evaluate information effectively, by extension assisting them to develop into long-life learners (Jiao \& Onwuegbuzie 2004; Sami \& Pangannaiah 2006; Singh \& Nazim 2008). This argument is in line with the principle of developing independent library users who are able to navigate the information arena in a logical, creative effective and 
efficient manner (Nithyanandam et al. 2006; Okoye 2013). As champions of information, user education librarians should be knowledgeable in pedagogy and instructional design and their knowledge should align with the diversification of the student population (Ringle 2014). Any user education approach that ignores the choice of an appropriate educational methodology will fail to encourage research inquiry and jettison the development of knowledge which could be achieved through participatory learning (Isiaka \& Olaide 2013; Jiao \& Onwuegbuzie 2004; Siddiqui \& Walia 2013; Umeozor 2013).

\section{Research methodology}

According to Schilling and Applegate (2007) the evaluation of educational library programmes usually includes both quantitative and qualitative measures. This study used both quantitative and qualitative research approaches, as well as triangulation. It used questionnaires for postgraduate students and interviews with subject librarians and academic coordinators. These data collection tools were presented sequentially with students surveyed first, followed by interviews with library and academic staff. The thinking behind this order was that students are likely to raise critical issues that would need to be corroborated from the two other categories of participants. Questions were asked to establish the effectiveness of user education for postgraduate students. The population for this study consisted of 1,202 postgraduate students in the College of Management at Westville Campus who were serviced by three subject librarians and six academic coordinators. The study drew a sample population of 291 postgraduate students through stratified and simple random sampling strategies. All the three subject librarians and five academic coordinators were interviewed. Of the 291 students, 205 responded to the questionnaire, yielding a good response rate of $70 \%$. To corroborate students' viewpoints, data was solicited from librarians and academic coordinators. Five out of six academic coordinators were interviewed $(83 \%)$ as were all three subject librarians.

\section{Presentation and discussion of findings}

The following section presents findings from the respondents arranged into dominant themes within each category. The results and discussion from the questionnaire and interviews with postgraduate students and the subject librarians and academic coordinators are presented.

\subsection{Findings from postgraduate students}

The results from postgraduate students are arranged according to theme.

\subsubsection{Awareness about user education}

Students were asked to indicate their level of awareness of user education programmes offered by the library. In particular, the question wished to ascertain whether respondents were aware of user education programmes offered by the library and how they obtained information about such programmes. The study found that the majority $(172 ; 84 \%)$ of the postgraduate students acknowledged that they knew about user education programmes offered by the library, whilst twenty-one (10\%) claimed that they had no knowledge of these programmes and twelve (6\%) did not respond to the question. The responses to the question about the source of information about user education programmes are captured in Table 1 below.

Table 1 Source of information about user education

\begin{tabular}{lcc}
\hline Source of information & Respondents & $\%$ \\
\hline My friends/colleagues & $165(80 \%)$ & 80 \\
My lecturer/supervisor & $105(51 \%)$ & 51 \\
My subject librarian & 112 & 55 \\
UKZN Library orientation week & 46 & 22 \\
UKZN Library website & 32 & 16 \\
Notice boards & 30 & 15 \\
Other library staff & 24 & 12 \\
My relatives & 10 & 5 \\
Head of academic department & 10 & 5 \\
\hline
\end{tabular}

The results reveal that most students obtained information about user education from friends or colleagues, followed by lecturers or supervisors and subject librarians. The study established that very few students acquired information during the orientation week or from the UKZN Library website, notice boards and other library staff. The fact that the library website, notice boards and other library staff members were scored low by the respondents is indicative of the fact that these library tools were not very effective for communicating or marketing user education programmes to postgraduate students. These results reflect that the dominant forms of communication are oral or personal modes (friends or colleagues, lecturers or supervisors, and subject librarians). In an era dominated by the use of social media Facebook and Twitter being popular with the majority of students - the use of social media tools as a means of 
communication needs to be developed. The alignment between the communication or marketing tools and the reality of the user cannot be overemphasised because, if there is a gap between the two, the message is not likely to reach the intended recipient.

\subsubsection{Importance of user education programmes}

A question was asked to determine whether postgraduate students realise, appreciate, or have a high regard for user education programmes. The intention of the question was to determine whether the students themselves see the probable value of user education to their own studies. All the students regarded user education programmes as integral to their education. The positive response meant that, in general, students recognise that user education can improve their library use, which can in turn have a positive effect on their studies. If, by their own admission, students recognise the value of user education, it can be assumed that they realise the relationship or interconnectedness between library use and success in academia. The notion of the correlation between the two variables is attested and advocated by various authors (Aderibigbe \& Ajiboye 2011; Bhatti 2010; Breen \& Fallon 2005; Hindagolla 2012; Isiaka \& Olaide 2013; Maduako 2013; Ogunmodede, Adio \& Odunola 2011; Owusu-Ansah 2004; Stone \& Ramsden 2014; Suleiman 2012; Umeozor 2013; Wong \& Webb 2011).

The determination of the relationship between user education and academic performance was beyond the scope of this study. The importance of the realisation of this relationship is that it embodies understanding and appreciation of the value of user education which is likely to increase the probability of using and exploiting library sources optimally and improve academic performance. However, it is not enough to declare the realisation of the value of user education if it is not coupled with commitment to participation in user education. The understanding of the importance of user education depends on the level at which the concept and/or practice is marketed by the library and also its perceived value. As indicated earlier, if marketing of user education programmes is inadequate, users will lack a clear and meaningful understanding of user education; consequently, response to user education programmes will be less than optimal.

\subsubsection{Attendance of user education initiatives}

The UKZN Library organises library orientation annually, usually at the beginning of the academic year. A question was asked to determine the extent to which students participate in user education. The results show that only eighty-seven $(42 \%)$ attended orientation programmes arranged for their departments. This concurs with what the librarians said when they indicated that, generally, about fifty students attend orientation sessions. Some of the respondents highlighted challenges associated with the timing of library orientation. One of these is the fact that orientation runs concurrently with the registration process; during this time students have not settled down and they have not established their information needs. These responses confirm the observation from the literature that most user education programmes fail because they are ill-timed.

Besides the library orientation presented at the beginning of the year, the library makes arrangements with the faculties to schedule training on electronic search and retrieval strategies for postgraduate students. About forty-six (22\%) students indicated that they have attended these user education training sessions. The students indicated that the maximum time allocated to these sessions was less than one hour. Based on the academic level of students, their needs and skills level, the quantity of information available, as well as the complexity of information technologies, the allocated time might compromise the depth and sufficiency of content in the training programmes. In addition to the user education interventions discussed above, some students voluntarily go to the library to ask for assistance from subject librarians. Clearly, the level at which users will approach subject librarians will depend on what Maduako (2013) and Blummer, Kenton and Song (2010) call a meaningful relationship between the librarians and the students. Further, the ability to engage the subject librarian proactively will be affected by the assertiveness and confidence that the user exudes. Assertiveness stems from the awareness and appreciation of the user's rights and the ethical obligation of the library towards its constituencies. It is critical that this relationship should be enhanced by the librarian in order to win over the trust, loyalty and commitment of the user.

The results indicate that student uptake of user education training is fairly low $(42 \%$ for library orientation and $22 \%$ for in-depth training). By their own admission, very few students attended user education training. The major reasons given by students for poor attendance of user education training include the time allocated for and timing of user education interventions. Given that the focus of this study is on postgraduate students, of which the majority are part-time and cannot attend any of the scheduled times, it is not surprising that the issue of timing surfaces as a challenge. The UKZN Library can consider scheduling some workshops during weekends and evening hours to try and reach students who are not available at other times.

\subsubsection{Aptitude of postgraduate students}

Most students (93\%) affirmed that they are capable of searching a few databases. They are aware that there are many more databases available to them than those they are currently using. With regards to searching information from the library catalogue, $55 \%$ of the respondents indicated that they are capable of conducting these searches independently (see Table 2 below). On the other hand, $45 \%$ of postgraduate students indicated that they still depend on subject librarians for assistance with information searching. As indicated by Ogunmodede, Adio and Odunole (2011), user education is a necessity because the average user may not easily comprehend how to use available information resources effectively. The purpose of user education is not to perpetuate dependency, but to develop independent and resourceful users (Coonan 2011; Isiaka \& Olaide 2013; Okoye 2013; Suleiman 2012). 
If postgraduate students still depend on the assistance of subject librarians, it shows that there is still a long way to go before users acquire a reasonable level of autonomy. However, this might not be an indication of the failure of user education interventions as there might be varying factors that affect the propensity to be independent users of library resources. Such factors might include inappropriate, ineffective and inefficient teaching methods and strategies, evident in both the content presented and the skillset of facilitators. But, since the determination of these factors was outside the scope of this study, a conclusive statement in this manner cannot be made.

Table 2: Ability to search information sources $(\mathrm{N}=184)$

\begin{tabular}{|c|c|c|c|c|}
\hline Ability of users & Yes & $\%$ & No & $\%$ \\
\hline I can perform information searches for some databases & 172 & 93 & 12 & 7 \\
\hline I can search the library catalogue independently & 123 & 55 & 82 & 45 \\
\hline $\begin{array}{l}\text { I am still dependent on the subject librarian for searching information from the } \\
\text { library }\end{array}$ & 82 & 45 & 102 & 55 \\
\hline
\end{tabular}

\subsubsection{Proposed improvements for user education programmes}

The study also revealed that all the respondents indicated that they needed more training in user education. They realise that the current user education programmes offered by the UKZN Westville Library are not sufficient to enable them to be independent, self-reliant and competent consumers of library resources. The programmes fall short of empowering them to become their own gatekeepers and liberated and autonomous consumers of knowledge (Aderibigbe \& Ajiboye 2011; Coonan 2011; Hindagolla 2012; Ogunmodede et al. 2011). In this regard, the students gave suggestions as to how the library could improve user education programmes:

- the library should contact academic departments to synchronise user education training with postgraduate activities;

- time allocated for user education should be extended and made flexible to accommodate students' needs;

- given that most postgraduate students are part-time, the library should offer user education training after hours and during weekends to cater for them;

- user education training should be offered through social network platforms or through other online media or interfaces;

- user education programmes should be compulsory for undergraduate students to prepare them for postgraduate studies in terms of adequate information searching and retrieval skills; and

- the library should assist visually impaired students by providing them with JAWS software that read aloud what appears on the personal computer screen.

\subsubsection{Support system: subject librarians}

The students were asked questions about how they perceive subject librarians as their support system. The study found that 181 students $(88 \%)$ knew their subject librarians; only twenty-three $(11 \%)$ indicated that they did not know their subject librarians. It emerged that most of those (64\%) who knew their subject librarians did so through their peers. Others $(32 \%)$ were informed about their subject librarians by their supervisors. The remaining $4 \% \mathrm{knew}$ of subject librarians from heads of departments, lecturers and library assistants. Given that some of the postgraduate students might not have experiences of using the library, it is important that information about subject librarians is clearly communicated through signage, institutional and library websites, Facebook, Twitter, and other types of social media. Given that about 112 students (55\%) knew their subject librarians and visited them often, it is important to promote subject librarians as critical elements of the library support system.

\subsection{Findings from subject librarians}

Coonan (2011) claims that in the evolving information-literate world, librarians need to shift focus from providers and gatekeepers of information to facilitators of learning. The results and discussion of the semi-structured interview with subject librarians are as follows.

\subsubsection{Time allocation and timing}

The subject librarian indicated that the UKZN Westville Library provides library orientation to all new students at the beginning of each semester. Orientation programmes offer a brief introduction to the services available to enable students to be confident in using library resources. The orientation programmes further inform library users about the sections of the library and how to access the various collections at Westville Campus Library in particular and UKZN Libraries in general. Overall, these programmes offer more basic and directional information about the library and its information services and resources. The programmes are organised by subject librarians or a user education librarian in consultation with academic staff. The library orientation programmes are offered at the beginning of each semester, and are held daily with three sessions of 45 minutes each day for three weeks. The sessions are largely interactive, with users being offered hands-on training where they are required to follow examples of searches retrieved from databases using the library 
'icatalogue'. Generally there are about fifty students per orientation session, though the number differs in terms of the study programmes.

These orientation programmes are supplemented by user education programmes which are held throughout the year. User education programmes cover in detail areas such as the navigation of the library website, use of e-resources (e-books, e-journals, and e-databases), availability of general library services, and guides to important national and international resources. These programmes involve working on a specific subject area where teaching is based on examples from within the discipline. For these programmes, academics are involved. Some academics request much longer sessions for their postgraduate users or training on specific areas for their students. One of most popular requests is for EndNote training.

When asked about the time allocated for user education and orientation programmes, the subject librarians stated that the time allocation was insufficient. They also raised the issue about the timing of library orientation and user education programmes, one that was also raised by students. Further, they indicated that library orientation occurred simultaneously with the registration of students within the School of Management, Information Technology and Governance. This timing is likely to affect the user education attendance by most of the students since most of them have not settled in and are busy with the registration process. The librarians indicated that user education programmes are offered during working hours which might be a challenge for postgraduate students who are mainly studying on a parttime basis. This assertion validated the students' responses presented earlier.

Attendance of both orientation and user education programmes is not compulsory; it is largely arranged on a departmental or faculty basis. It has emerged in the literature that, if user programmes are not credit bearing, it might be difficult to enforce attendance or commitment. Despite the limitation, it is the prerogative of the library to foster information skills amongst its main clientele including postgraduate students.

\subsubsection{Marketing user education programmes}

User education programmes aim to make all users aware of the information resources available, both directly in the library and from external sources, and enable users to enjoy the search for information (Aderibigbe \& Ajiboye 2011; Hanson 1984; Maduako 2013). Marketing is critical to user education as a lever for communicating, popularising and creating awareness among stakeholders. The subject librarians emphasised that user education programmes are marketed through library brochures, the library website and word of mouth. One subject librarian acknowledged that "the marketing tools used to promote user education were not successful; this was shown by the poor attendance during the user education sessions".

Although there is no evidence about the direct relationship between marketing and poor attendance it is interesting to note that the subject librarians perceive a link between the two variables.

\subsubsection{Evaluation of user education programmes}

Blummer, Kenton and Song (2010) suggest that libraries should assess their existing programmes and determine if they meet students' information needs. The subject librarians were asked questions about the assessment of user education programmes, or lack thereof. The findings highlighted that the UKZN Library does not have an assessment tool for user education programmes. The study also revealed that previously evaluation forms were used to assess the effectiveness of the training interventions. However, these forms were no longer used. One subject librarian stated that "to be able to provide relevant and responsive user education programmes, it is critical that these programmes are regularly evaluated".

Fjällbrant (1977) suggested that one way of evaluating user education programmes is to collect and analyse the input. Input should be analysed in terms of education potential, variables affecting the educational process, and the end product or output. Schilling and Applegate (2012) and Dewald (1999) state that there is an increasing need for librarians to provide tangible evidence that user education and/or information literacy programmes are valid and legitimate. They further state that, without systematic evaluation, libraries do not have adequate information to determine the effectiveness, efficiency and impact of existing training programmes, and thus they have no basis to determine whether programmes should be continued, expanded, modified or discontinued (Schilling \& Applegate 2012).

\subsubsection{Challenges faced by subject librarians}

One of the objectives of the study was to examine the problems experienced by subject librarians in terms of user education programmes. The participants generally indicated that the main challenges for user education included the students' lack of searching and retrieval skills; relatively low attendance of user education training by postgraduate students; students' lack of motivation; insufficient time allocated to training; timing of training interventions; marketing of programmes; lack of marketing resources including expertise; and insubstantial partnerships between stakeholders (academics and students).

\subsection{Findings from academic coordinators}

The academic coordinators from the School of Management, Information Technology and Governance were interviewed to obtain their opinions and perspectives of user education for postgraduate students in UKZN. 


\subsubsection{User education for postgraduate students}

The academic coordinators acknowledged the importance and probable benefits of user education for postgraduate studies. They viewed the library as having the necessary resources that would help develop students' research skills, which would in turn support their tertiary studies and empower them in their future careers. One of the coordinators stated that "if students acquire sufficient knowledge and skills for information searching and retrieval, they are likely to become active and independent learners with improved academic performance and research output".

It emerged from the findings that postgraduate students do not perform well in their research projects; as a result the research output of postgraduate students is low. Generally, the participants agreed that the low research output might be caused by the fact that the majority of students do not have sufficient aptitude for searching and retrieving information, and have poor research skills. Further, one participant stated that "postgraduate students seem not to have time to visit the library to find information required for their studies; they instead use shortcuts to do their work which results often in poor submissions". This corroborates the students' responses presented earlier that some aspects of the user education training interventions offered by the library are somehow inadequate and do not enable them to be effective, efficient and self-sufficient.

The findings revealed that academic coordinators were not familiar with most of the services provided by the library. Most of the participants indicated that they are not aware of any formal user education programmes or strategies in place to support postgraduate research. One participant in particular stated that "postgraduate research support in the School of Management, Information Technology and Governance at UKZN was not sufficient".

The participants generally indicated that due to a heavy work load most of them do not have sufficient time to visit the library. One participant specified that "it is important for academics to familiarise themselves with the information resources provided in the library so that they can transfer the knowledge and skills acquired to the students".

Some of the respondents also indicated the importance of cooperation between the students, subject librarians and academics to enhance user education attendance by postgraduate students. Meulemans and Brown (2001) state that, for librarians to provide effective user education to students, they should be partners with academics and students. Aderibigbe and Ajiboye (2011) say that, before librarians plan user education programmes, they should determine the information needs of users, and then determine how much users know about information organisation, access and use.

\section{Conclusions and recommendations}

The intention of this study was to evaluate the nature and application of postgraduate user education programmes in the School of Management, Information Technology and Governance at the Westville Campus of UKZN. The library offers library orientation at the beginning of each year. It also offers faculty-specific user education and impromptu assistance from subject librarians and other library staff to students who come to the library for help. The findings revealed that, although the levels of awareness about user education and the realisation of the importance of user education are high amongst postgraduate students, they do not translate into a high uptake of user education training programmes (which was $42 \%$ of those who responded to the questionnaire for orientation and $22 \%$ for user education sessions). The statistics reveal that, contrary to the positive assertions made by students about user education, the attendance of user education initiatives is fairly low. This low uptake can in some measure be attributed to the ineffectiveness or insufficiency of marketing tools used to promote user education. Marketing efforts are largely oral-based or traditional (that is, via brochures). Postgraduate students stated a preference for social media platforms for information about user education. Similarly, the time allocated for and timing of user education programmes can be a contributing factor to low attendance levels. Some students indicated a preference for more offerings and a rescheduling of offerings to evenings or even weekends to accommodate part-time students. With regards to students' aptitude, the majority of respondents (55\%) conceded that they are still reliant on the subject librarian for searching for information from the library. This level of dependency runs against the grain of postgraduate education which upholds autonomy, self-reliance and life-long learning.

One can surmise that some postgraduate students in the university do not have a strong library background or culture. In such a situation the academic library as an intermediary needs to intensify its efforts to close the gap between users' disposition and experience and the wealth of information available to them. As champions of information user education, librarians should be knowledgeable in pedagogy and instructional design and their knowledge should align with the diversification of the student population (Ringle 2014). In conclusion, librarians need to go beyond simply demonstrating to students where to click on a webpage (Sellie 2011); they need to develop essential teaching skills in line with new educational and technological trends (Saunders 2002).

Another important factor that emerged from this study is the importance of a close relationship between academics, librarians and students in order to synchronise plans, expectations, challenges and opportunities (Aderibigbe \& Ajiboye 2011; Ogunmodede et al. 2011). The UKZN Westville Campus Library needs to strengthen this triad partnership as it is a critical foundation for determining the users' actual needs - critical in improving students' research profiles. Although there are pockets of good behaviour in the user education practice, there is a need to reconsider the content, the mode, the scope and overall relevance and suitability of user education programmes in line with varied user needs. Based on the issue of the diversity of the student population, it would be unfortunate for the library to offer a 'one size fits all programme' as evidenced by the limited training interventions. The extension of user education programmes in terms of content, depth and teaching strategies and methods is critical. There is also a need to consider issues of appropriateness, effectiveness and efficiency of instructional methods and pedagogical matters. In the same vein, the need constantly to evaluate the impact, effectiveness and efficiency of user education programmes, as well as the skillsets of librarians, 
cannot be overemphasised. In conclusion, it is hoped that these findings will enable the UKZN Westville Campus Library to reflect and seriously consider possibilities and prospects that are likely to enhance its initiatives, maximize library services and ultimately benefit the user.

\section{Acknowledgments}

This study was made possible by the Carnegie Research Academy and UKZN, Westville Campus, South Africa.

\section{References}

Aderibigbe, N. A. and Ajiyibode, B. A. 2011. User education program as determinant of electronic information resources usage in Nimbe Adedipe University Library, Nigeria. The Electronic Library, (31): 244-255.

Akakandelwa, A. 2010. An assessment of user education in academic libraries: the case of the University of Zambia. The Electronic Library, (31): 204-215.

Anyira, I. E. 2011. The anatomy of library users in the 21st century. Library Philosophy \& Practice (e-journal), Paper 535. [Online]. http://digitalcommons.unl.edu/libphilprac/535 (3 December 2014).

Arp, L. 1993. An introduction to learning theory. In Sourcebook for Bibliographic Instruction. K. Branch and C. Dunsenbury, Eds. Chicago, IL: Bibliographic Instruction Section, Association of College and Research Libraries. 515.

Atherton, J. 2005. Learning and teaching: constructivism in learning. [Online]. http://www.learningandteaching.info/learning/constructivism.htm (2 December 2014).

Bhatti, R. 2010. An evaluation of user-education programmes in the university libraries of Pakistan. Library Philosophy \& Practice (e-journal), Paper 316. [Online]. http://www.webpages.uidaho.edu/ mbolin/bhatti2.htm (26 November 2013).

Birch, R. G. 2012. The impact of information literacy instruction on the library anxiety and information competency of graduate students. D.Ed. thesis. Olivet Nazarene University.

Blummer, B., Kenton, J. M. and Song, L. 2010. The design and assessment of a proposed library training unit for education graduate students. Internet Reference Services Quarterly, 15: 227-242.

Brandenburg, M. D. and Song, J. 2012. Broadening instructional scope with network visualization. Journal of the Medical Library Association, 100: 313-316.

Breen, E. and Fallon, H. 2005. Developing student information literacy to support project and problem-based learning. In Handbook of Enquiry \& Problem Based Learning. T. Barrett, I. Mac Labhrainn and H. Fallon, Eds. Galway: CELT.

Bundy, A. 2004. Australian and New Zealand Information Literacy Framework: Principles, Standards and Practice. Adelaide: Australian and New Zealand Institute for Information Literacy. [Online]. http://www.anziil.org/index.htm. (18 May 2013).

Chen, L. C. 2012. The effects of integrating information literacy into science instruction on seventh-grade students' problem-solving and academic achievement. IEEE International Conference on, Advanced Learning Technologies. 46 July 2012. Rome, Italy: ICALT. [Online]. DOI:10.1109/ICALT.2012.2 (6 March 2014).

Chen, K. \& Lin, P. 2011. Information literacy in university library user education. Aslib Proceedings, 63: $399-418$.

Chinyere, E.U. 2014. Effects of library instruction on satisfaction with the use of library and its services: a study of undergraduate students in five universities in the southern part of Nigeria. European Scientific Journal, 10 (13).

Coonan, E. 2011. A new curriculum for information literacy: transitional-transferable-transformational. Cambridge: Cambridge University Library. [Online]. http://arcadiaproject.lib.cam.ac.uk/docs/theory.pdf (25 November 2013).

Cooperstein, S.E. and Kocevar-Weidinger, E. 2004. Beyond active learning: a constructivist approach to learning. Reference Services Review, 32(2):141-148.

Dewald, N.H. 1999. Web-based library instruction: what is good pedagogy? Information Technology and Libraries, 18(1): 26-31.

Elmborg, J. 2006. Critical information literacy: implications for instructional practice. The Journal of Academic Librarianship, 32(2): 192-199.

Fallon, H. and Breen, E. 2012. The changing role of the academic library in learning and teaching. In Emerging Issues II: the changing roles and identities of teachers and learners in higher education. B. Higgs and M. McCarthy, Eds. Cork: NAIRTL. 141-152.

Fawley, N. E. and Krysak, N. 2012. Information literacy opportunities within the discovery tool environment. College \& Undergraduate Libraries, 19(2-4): 207-214.

Fjällbrant, N. 1977. Evaluation in a user education programme. Journal of Librarianship and Information Science, 9(2): 8395.

Hanson, JR. 1984. The evaluation of library user education with reference to the programme at Dorset Institute of Higher Education (DIHE). Journal of Librarianship and Information Science, 16(1): 1-12.

Hindagolla, B. M. M. C. B. 2012. Restructuring of user education programmes in university llibraries from user perspectives: a case study. Journal of University Librarians Association of Sri Lanka, 16: 19-33.

Jacobs, H.L.M. 2008. Information literacy and reflective pedagogical praxis. The Journal of Academic Librarianship, 34(3):256-262.

Jiao, Q. G. and Onwuegbuzie, A. J. 2004. The impact of information technology on library anxiety: the role of computer attitudes. Information Technology and Libraries, 23(4): 138-144..

Jiyane, G.V. and Onyancha, O.B. 2010. Information literacy education in academic libraries and LIS schools in institutions of higher education in South Africa. South African Journal of Libraries and Information Science, 76 (1): 11-24. 
Kannappanavar, B. U. and Swamy, H. M. C. 2012. User education in Agricultural Science university libraries in India with special reference to South India. Library Philosophy and Practice (e-journal), Paper 720. [Online]. http://digitalcommons.unl.edu/libphilprac/720.

Maduako, P. U. 2013. User education and library use in Colleges of Education in Abia and Imo States. . Library Philosophy and Practice (e-journal), Paper 955. [Online]. http://digitalcommons.unl.edu/libphilprac/955.

McCauley, D. 2006. Constructivist learning theory and the reference librarian. [Online]. http://tauranga.kete.net.nz/en/tauranga_city_libraries_history/topics/show/1007-constructivist-learning-theory-andthe-reference-librarian-2006-by-debbie-mccauley (11 January 2014).

Meulemans, Y. N. and Brown, J. 2001. Educating instruction librarians: a model for Library and Information Science education. Research Strategies, 18: 253-264.

Mohammadi, M., Moghaddam, A. I. and Yeganeh, M. E. 2008. Students' perception of the impact of user education on the use of reference resources: an Iranian experience. Library Philosophy and Practice (e-journal), Paper 199. [Online]. http://digitalcommons.unl.edu/libphilprac/199.

Nithyanandam K., Kanniyappan, E., Dhanakar, M. A. and Rajasekar, V. 2006. User education programmes and academic libraries. Library Philosophy and Practice (e-journal), Paper 774. [Online]. http://digitalcommons.unl.edu/libphilprac/774.

Ogunmodede, T. A., Adio, G. and Odunola, O. A. 2011. Library use education as a correlate of use of library resources in a Nigerian University. Library Philosophy and Practice (e-journal), Paper 604. [Online]. http://digitalcommons.unl.edu/libphilprac/604.

Okoye, M. O. 2013. User education in Federal University libraries: a study of trends and developments in Nigeria. Library Philosophy and Practice (e-journal), Paper 942. [Online]. http://digitalcommons.unl.edu/libphilprac/942.

Owusu-Ansah, E.K. 2004. Information literacy and higher education: placing the academic library in the centre of a comprehensive solution. Journal of Academic Librarianship, 30 (1): 3-16.

Oyedipe, W.J. and Okewale, S.O. 2012. A survey of user education program for distance learners in three selected universities in Ogun State. The Information Manager, 12 (1\&2).

Ringle, M. 2014. Redesigning library instruction: a collaborate process. Indiana Libraries, 33(2): 68-70.

Sami, L. K. and Pangannaiah, N. B. 2006. 'Technostress': a literature survey on the effect of information technology on library users. Library Review, 55: 429-439.

Saunders, L. 2002. Teaching the library: best practices. Library Philosophy \& Practice (e-journal), Paper 51. [Online]. http://digitalcommons.unl.edu/libphilprac/51.

Schilling, K. and Applegate, R. 2007. Evaluating library instruction: measures for assessing educational quality and impact. ACRL Thirteenth National Conference. 29 March - 1 April. Baltimore, Maryland: ACRL. [Online]. http://www.ncbi.nlm.nih.gov/pmc/articles/PMC3484955/ (25 November 2014).

Schilling, K. and Applegate, R. 2012. Best methods for evaluating educational impact: a comparison of the efficacy of commonly used measures of library instruction. Journal of Medical Library Association, 100(4): 258-269. [Online]. http://www.ncbi.nlm.nih.gov/pmc/articles/PMC3484955/ (25 November 2014).

Sellie, A. 2011. 'Critical Teaching in the Library' Rev. of Critical Library Instruction: Theories and Methods. Feminist Collections, 32(1): 10-12.

Siddiqui, S. and Walia, P. K. 2013. A comparative analysis of Library and Information Science post graduate education in India and UK. Library Philosophy \& Practice (e-journal), Paper 941. [Online]. http://digitalcommons.unl.edu/libphilprac/941/

Singh, D. K. and Nazim, M. 2008. Impact of information technology and role of libraries in the age of information and knowledge societies. 6th International CALIBER-2008. 28-29 February \& 1 March. University of Allahabad, Allahabad: INFLIBNET Centre. 28-34. [Online]. http://eprints.rclis.org/11355/1/caliber_1.pdf (20 November 2014).

Stone, G. and Ramsden, B. 2014. Library impact data project: looking for the link between library usage and student attainment. College and Research Libraries (pre-print). [Online]. http://crl.acrl.org/content/early/2012/11/08/crl12406.full.pdf (25 January 2015).

Suleiman, S. A. 2012. User education programs in academic libraries: the experience of the International Islamic University Malaysia students. Library Philosophy \& Practice (e-journal), Paper 774. [Online]. http://digitalcommons.unl.edu/libphilprac/774.

Syaikhu, A. 2013. Building interest in Agricultural research through user education activities. IASL Conference Reports, 231-235.

Tiefel, V. M. 1995. Library user education: examining its past, projecting, its future. Library Trends, 44 (2): 318-38.

University of KwaZulu-Natal (UKZN). 2013. University of KwaZulu-Natal Libraries. [Online]. www.ukzn.ac.za (29 November 2014).

Umeozor, S. N. 2013. Human resources, user education marketing strategy, and students' use of library services in some Nigerian Federal Universities. Library Philosophy \& Practice (e-journal), Paper 888. [Online]. http://digitalcommons.unl.edu/libphilprac/888/.

University of South Africa. 2007. The Unisa 2015 strategic plan. [Online]. http://www.unisa.ac.za. (11 August 2014).

Whitmire, E. 2002. Academic library performance measures and undergraduates' library use and educational outcomes. Library \& Information Science Research, 24: 107-128.

Wong, S.H.R. and Webb, T.D. 2011. Uncovering meaningful correlation between student academic performance and library material usage. College and Research Libraries, (72) 4: 361-370. 
Wooliscroft, M. 1997. From library user education to information literacy: some issues arising in this evolutionary process. [Paper]. COMLA Workshop, Gabarone, Botswana. [Online]. http://www.webpages.uidaho.edu/ mbolin/agyengyasi.htm. (12 April 2015). 